\title{
A Practical Study of Smart Education in College English Teaching
}

\author{
Jie Xiao \\ School of Foreign Languages \\ Wenhua College \\ Wuhan, China
}

\author{
Weimin Qi* \\ School of Physics and Information Engineering \\ Jianghan University \\ Wuhan, China
}

\author{
Qun Hou \\ School of Physics and Information Engineering \\ Jianghan University \\ Wuhan, China
}

\begin{abstract}
The study is aimed to apply the smart education concept to college English teaching. In the specific operation, the author recommends to students the use of online open classes, micro-classes, mobile APPs and other software tools to integrate online and offline teaching curriculum resources. By relying on online technology, students can realize online interaction and mobile situational conversations between teachers and students in and out of class. Through the study of relevant successful practices, the work summarized the advantages of smart education compared with traditional teaching. By teaching practice, it is proved that smart education is conducive to promoting students' interest in learning and learning effects.
\end{abstract}

\section{Keywords—Smart Education; College English; Practice}

\section{INTRODUCTION}

According to the new curriculum concept, educational reform should go beyond pure knowledge education and the single direction of examinations and tools, aiming at improving learners' metacognitive strategies and enlightening their wisdom in life, and changing from cultivating "intellectuals" to cultivating "wise men".

Smart education explores the promotion of metacognitive strategies under the background of "Internet +" era. It will awaken classroom vitality and guide teachers' professional growth, and enable students to create their own language knowledge system, so as to ultimately achieve the goal of promoting metacognitive strategies.

\section{OVERVIEW OF RESEARCH AT HOME AND ABROAD}

The study of wisdom began in the late 1980s. Western wisdom theory can be divided into four schools. Jean Piaget's cognitive development theory expounds wisdom from the perspective of cognitive development. Sternberg' information processing theory explores the process and steps of the generation of wisdom, but lacks a discussion on the essence and principle of wisdom. Snow's theory of learning points out that interest in learning is very important to the generation of

This research was financially supported by the Education Science Planning Project of Hubei Province, China (Grant No. 2017GB146) wisdom, but his theory lacks the elaboration of the theory of holistic wisdom. Jansen's theory of factor analysis mainly aims at the problems that have been systematized and clarified and lacks the explanation of the essence and scope of wisdom.

In the 21st century, the concept of "smart education" has attracted wide attention from the educational and psychological circles. In 2001 Sternberg put forward the "theory of balance of wisdom", discussing the purpose of smart education, and then put forward sixteen principles and six methods of smart education [1]. In 2000 Gardner put forward the theory of multiple intelligences and put forward eight main intelligences including linguistic intelligence, logical intelligence and spatial intelligence [2]. In 2008 Michel Ferrari and Georges Potworowski proposed "Teaching for Wisdom from a Cross-cultural Perspective"[3]. In 2004 Tingchu Zhang put forward the new curriculum plan: information, interest, inquiry, intelligence, intuition [4].

To sum up, scholars have paid much attention to the wisdom education itself, but they have little research on how to use modern information technology to promote the integration of College English and smart education. Based on the idea of cultivating intelligent talents, combined with information technology conditions and innovative research methods, and guided by language learning theory, this study explores ways and means of College English smart education. It is hoped that this study will not only improve students' language learning effects but also enhance their metacognitive strategy level[5].

\section{THE CHARACTERISTICS AND NECESSITY OF SMART EDUCATION IN COLLEGE ENGLISH}

Smart education is a direct way to help people build a complete system of wisdom. Its teaching purpose is to guide students to discover their own wisdom, develop their own wisdom, apply their own wisdom and create their own wisdom. Smart education has the following two characteristics: individualized guidance and all-round interaction. 


\section{A. Individualized Guidance}

Smart education can combine traditional superior educational resources with new science and technology. In the process of smart education, all kinds of information of teachers and students can be timely perceived by the smart environment. Teachers can find out effective learning resources through data mining and analysis, so as to recommend suitable learning resources for students.

\section{B. All-round Interaction}

Interactive teaching is a kind of teaching mode, which regards the classroom teaching process as a dynamic interactive teaching process. Through the smart education environment, the realization of interactive teaching is more diversified. In addition to the interaction between teachers and students in the classroom, teachers and students can also use the smart interconnected application platform to achieve threedimensional, efficient and sustainable interaction between teachers and students.

For college English teaching in China, in the traditional classroom, students receive intensive and meticulous language input and complete a large number of exercises after class in order to consolidate classroom learning tasks. However, English education is a dynamic and long-term project. It is difficult to achieve the goal of language knowledge learning and language skills development only by relying on limited classroom learning. Therefore, it is a very meaningful teaching attempt to make full use of Internet information resources, expand the breadth and depth of learning resources, enhance the effectiveness of learning, cultivate students' learning wisdom and ability, and construct the smart education in college English in accordance with the characteristics of English subject and students' learning rules.

\section{PRACTICAL RESEARCH ON SMART EDUCATION IN COLLEGE ENGLISH TEACHING}

Smart education in College English teaching includes teaching links, teaching methods, and the effective and unified arrangement of knowledge cohesion in and out of class. Combining with the author's actual teaching situation, the following arrangements are made for smart education in college English teaching:

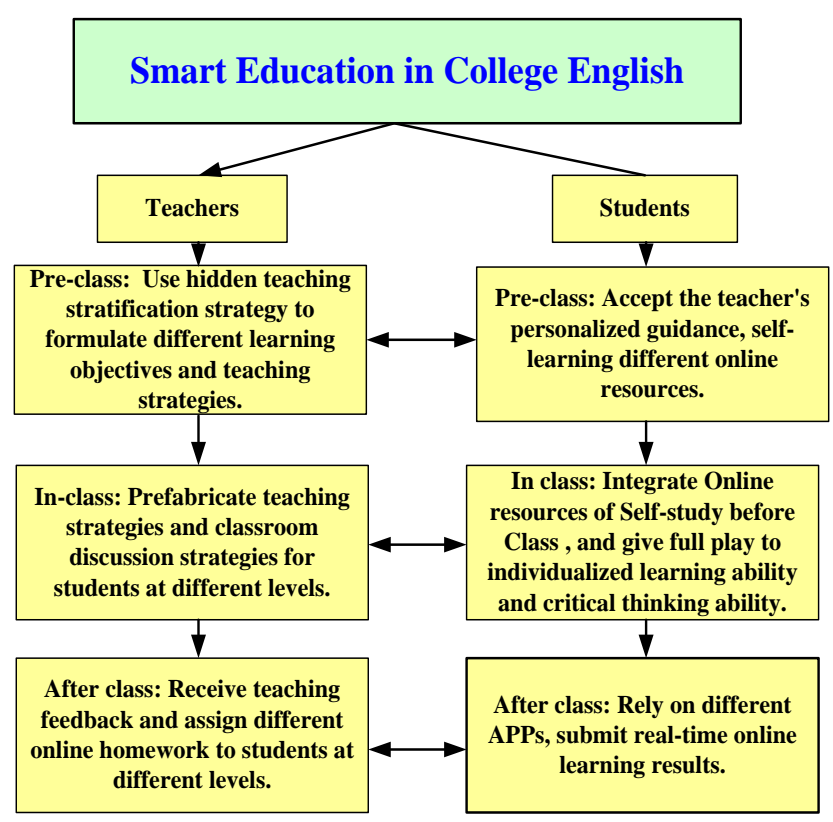

Fig. 1. Research on "smart education in college English "

\section{A. Pre-class Guidance and Preview}

This stage includes the related teaching activities of teachers and students in the pre-class stage. According to the actual learning level and potential trend of students, students are implicitly divided into three levels: high, middle and low, and different learning goals are set for students at different levels, and different teaching strategies are prefabricated. Teachers should divide all students into groups, and each group should include students at all levels. Teachers should clearly express their teaching objectives, teaching process and requirements to students, but they cannot inform students of their level, so as to avoid the inferiority complex of weak students. Teachers choose different supplementary materials for online teaching according to different levels of students, and assign tasks with different difficulties, and issue them in groups. Members of the group assign their own tasks[8]. In order to facilitate the interaction between teachers and students, each class has established communication tools such as QQ group for English learning.

In the pre-class preview stage, students will consciously choose the appropriate preview tasks according to their learning ability. The supplementary contents of online learning prepared by teachers for students include VOA Special English, MOOC course, Netease Cloud Classroom and Netease Open Course designed to meet the needs of students at different levels.

\section{B. Teaching and Learning in Class}

In the course of teaching and learning, in line with the principle of hidden stratification, the author arranges the contents of VOA Special English, Netease Cloud Classroom and Netease Open Class before class. For the middle and lower-level students, the author lets them mainly retell the listening information orally in VOA Special English. For 
students with high English proficiency, the author needs them to convey the main information in "Netease Cloud Classroom" and "Netease Open Class" in English. Many of the contents of these two APPs are from foreign teaching contents, with more information and more critical ideas. In order to avoid the adverse reactions of the lower level students, the author still assigns listening assignments from Netease Cloud classes to all students, but classroom questioning mainly focuses on high-level students. High-level students have been trained in listening and critical thinking, and low-level students are also involved in it, aiming at high-level students to guide their own direction.

In the process of listening practice, the author, in line with the principle of implicit stratified teaching, assigns all the exercises to students. In classroom testing, lower and middlelevel students retell special English mainly, while high-level students retell the main idea in Netease classroom. In this way, it not only avoids the sense of alienation between teachers and students in explicit stratified teaching, but also achieves the aim of stratified teaching.

\section{Feedback after Class}

Feedback mainly examines students' abilities in reading, speaking and writing. Different methods are used to evaluate students' proficiency.

Reading ability can be divided into loud reading and comprehensive reading. In order to train the ability of loud reading, the author recommends the use of "fluent English speaking" APP. The content of this APP is short and the intonation is gentle, unlike voice dubbing, which needs plenty of emotion. The content is relatively easy to imitate. In the aspect of comprehensive reading, the author recommends "Daily English Reading" and "Congke class" APPs. Teachers choose a section of "Congke class" as the content of students' self-study after class, and use it as the expansion of classroom learning. "Daily English Reading" is similar to online manuscripts of English abstracts, and the length of the text is appropriate. Teachers will arrange reading materials in class, and students will give oral reports in the next class.

In order to train the ability to speak, the author introduces "English interesting dubbing" APP. The author does not emphasize that students use a dubbed audio uniformly. The author emphasizes that students are free to choose dubbing audio according to their own speaking characteristics, timbre types, interests, likes and dislikes. Within 1-2 minutes, each dubbed passage will have natural clauses in English. The original voice will be repeated continuously, and the students will follow and read aloud until they think their voice is very close to the original. In order to motivate students, teachers have set up English learning QQ group and asked students to upload dubbing works to the group in which the teacher and students can appreciate and evaluate the works together. In order to make their dubbing works perfect for everyone to appreciate, every 5 minutes' dubbing works, students need 1-2 hours to polish. In English learning groups, students' dubbing is not only evaluated by teachers, but also enables students to learn from each other and evaluate each other. This has stimulated everyone's enthusiasm for English dubbing and found interest and confidence in English learning. The author finds that the dubbing of students does not necessarily depend on their English proficiency. Some students are easy to get into roles and passionate; some are good at imitating the tone of characters; others are good at dealing with details. Although their English proficiency is not necessarily good, the dubbing works they produce are of the highest quality. This example shows that the criteria of language learning should be more diversified, not only related to words and grammar. Moreover, the improvement of learners' language sense and passion is also a sign of language progress.

In order to train students' writing ability, the author recommends that students use "corrective network". Based on corpus and cloud computing technology, the "corrective network" provides automatic online marking service for English compositions. It can give scores, comments and sentence-by-sentence comments in time. It can improve the efficiency of teachers' marking English compositions and students' English writing ability.

Promote learning by singing. The author recommends the use of "National Sing Song" APP to encourage students to learn and sing English songs, which can not only promote English learning, but also increase talent. The author considers that through training, students can organize English song contests to inspire everyone's enthusiasm for learning English.

\section{Establishment of Digital Files for Students' Language Learning}

The author requests students to take photos and upload notes in each class. This method is tedious though. But after a long time, students become accustomed to it and naturally acquire the correct learning habits and methods, which also promotes the improvement of students' metacognition. The improvement of metacognition is to stimulate students' interest in learning, enhance their awareness of learning and selflearning ability.

\section{E. Learning Tests}

The author's curriculum testing mainly has three latitudes: learning situation testing, language skills upgrading, and the development of autonomous learning ability. The main purpose of the test is to test students' mastery of face-to-face courses. The improvement of language skills is mainly reflected in the quality of students' learning outcomes in Online Autonomous learning. The development of selfregulated learning ability examines students' ability to deal with difficulties and their comprehensive quality performance in self-regulated learning. The process that students encounter difficulties and solve them in using APP is the process of improving their autonomous learning ability. Autonomous learning can improve metacognition. Teachers should believe that students have the ability to learn independently. Teachers' task is to radiate students' awareness of self-learning.

\section{F. Selection of Learning APP}

The selection of learning APP is guided by the principle of "planning, execution, testing and promotion". When selecting an APP, the author first implements it on a small scale, with obvious effect, and then extensively promotes it. Students 
have a strong enthusiasm for learning, but they are still ignorant about the choice of learning tools. Teachers are required to give guidance and help them.

\section{ADVANTAGES OF SMART EDUCATION}

Smart education combines traditional classroom teaching with online teaching, and online teaching can deepen, widen, intellectualize and entertain the traditional learning process. The application of modern information technology can not only arouse students' interest in learning, but also deepen their learning process and effectively improve their learning efficiency. Smart education has the following advantages:

\section{A. Integration of Diverse Learning Resources, Means and Materials}

The integration of diverse learning resources, means and materials enriches the teaching content and promotes the wisdom of teaching process and teaching effect. Under the smart education mode, Internet technology is applied to college English teaching, which realizes the real-time integration and sharing of teaching technology and teaching resources. For learners, according to their actual level and needs, students can find their own learning resources and learning ways in the infinite rich network platform, which can mobilize students' learning motivation, improve learning efficiency, and consciously integrate smart learning means into their own learning process.

\section{B. The Change of Teaching Mode}

The teaching mode has changed from one-way teaching to interactive learning mode, which improves students' self-study ability and enriches teachers' teaching design level and teaching methods.

Under the traditional teaching mode, teachers transmit knowledge to students unilaterally while students learn knowledge passively, and the interaction between teachers and students is limited. Under the smart education mode, teachers first assign pre-online learning tasks to students, and promptly ask students to make learning feedback, which puts forward higher requirements for students' self-learning ability. In the subsequent classroom learning, through the implicit stratified teaching, teachers constantly expand knowledge, make an allround evaluation of students, and consciously re-stratify students according to their performance, and design the next teaching plan. This is a dynamic teaching process, which not only concentrates the advantages of teaching, exercises students' thinking, but also promotes the improvement of teaching quality, and teaching benefits teachers as well as students.

\section{CONCLUSION}

Smart education infiltrates into the practice of individualized College English teaching. It can make full use of Internet teaching resources, enrich teaching content and practice, mobilize learners' comprehensive learning ability, and enlighten learners' learning wisdom. College English smart education not only promotes the progress of students' English learning, but also enriches the author's teaching experience. Teaching and learning is the greatest wish of every educator. experience.

\section{ACKNOWLEDGMENT}

This research was financially supported by the Education Science Planning Project of Hubei Province, China (Grant NO. 2017GB146), also supported by the Project of Wuhan Science and Technology Bureau(Project Number: 2017010201010124).

\section{REFERENCES}

[1] Martinez, S. L., and Stager, G. S., "Invent to Learn: Making, thinking, and engineering in the classroom, " Constructing modern knowledge press, 2013.

[2] J. Gardner, R.C., and Lambert, W.E. "Attitudes and Motivation in Second Language Learning, ” Rowley, MA: Newbury House, 1972 , pp.68-78.

[3] Michel Ferrari and Georges Potworowski, "Teaching for Wisdom: Cross-Cultural Perspectives on Fostering Wisdom, ” vol. III, Springer, 1963, pp. 448-456.

[4] Tingchu Zhang, "Curriculum and Teaching Philosophy," Beijing: People's education press, 2003, pp.540-561.(In Chinese)

[5] Jie Xiao, "Research on the College English Teaching on the Implici Stratification Mode, " proceedings of the international conference on Education, Sports, Arts and Management Engineering. Atlantis Press, 2016, pp. 1027-1030

[6] Jie Xiao, "Research on Multidimensional Cultivation of College English Learning Strategies under the Condition of Information Technology in Application Oriented Universities, ” proceedings of the international conference on Education, Sports, Arts and Management Engineering. Atlantis Press, 2016, pp. 267-271 